\title{
A Claisen rearrangement route to novel electron-rich perylene dyes
}

\author{
Djan Baffoe, ${ }^{\text {a }}$ Terrill D. Smith, ${ }^{\text {a }}$ Mark A. Penick, ${ }^{\text {a }}$ Mathew P. D. Mahindaratne, Lorenzo \\ Brancaleon, ${ }^{b}$ and George R. Negrete*,a
}

${ }^{a}$ Department of Chemistry and ${ }^{b}$ Department of Physics, University of Texas at San Antonio, One UTSA Circle, San Antonio, TX 78249-0661, USA

E-Mail: george.negrete@utsa.edu

\begin{abstract}
A combined tandem Friedel-Crafts annulation/Claisen rearrangement strategy was developed for the preparation of tetrasubstituted perylenes. Diallyloxyoctahydroperylene was prepared from commercially available 1,2,3,4-tetrahydronaphth-1,5-diol and oxidized with chloranil to the perylene analogue. Claisen rearrangement followed to the novel 2,8-diallylperylene-3,9-diol, which was acylated in situ to the corresponding dioctanoyl ester. These results show that allyloxyperylene undergoes Claisen rearrangement efficiently, while partially hydrogenated analogue generates multiple products under identical conditions.
\end{abstract}

Keywords: Perylene, Claisen rearrangement, aromatization, polycyclic aromatic hydrocarbon

\section{Introduction}

Emerging dye applications in photovoltaics and photonics are prompting vigorous effort to increase the accessibility of novel perylene analogues. ${ }^{1}$ Perylenes bearing electron-donating substitutents are attractive as organic dyes for solar cells due to predicted stability of the radical cations generated upon photoelectron emission. ${ }^{2}$ Most novel perylenes are prepared via functionalization of commercially available perylene diimides, ${ }^{3}$ which in turn are obtained upon oxidative coupling of the corresponding naphthalene imides. Stepwise coupling of halonaphthalenes followed by oxidative annulation has also been reported but is less common. ${ }^{4}$ Our laboratory recently disclosed a novel route to 3,9-dialkoxyperylenes via Tandem FriedelCrafts Annulation (TFCA) of tetralin analogues (Scheme 1). ${ }^{5}$ Herein, we report an extension of this approach for the preparation of novel, dialkoxyperylenes that bear allyl groups via Claisen rearrangement. The target products bear electron-donating allyl groups, which also provide sites for attachment in novel photonic materials. ${ }^{6}$ 


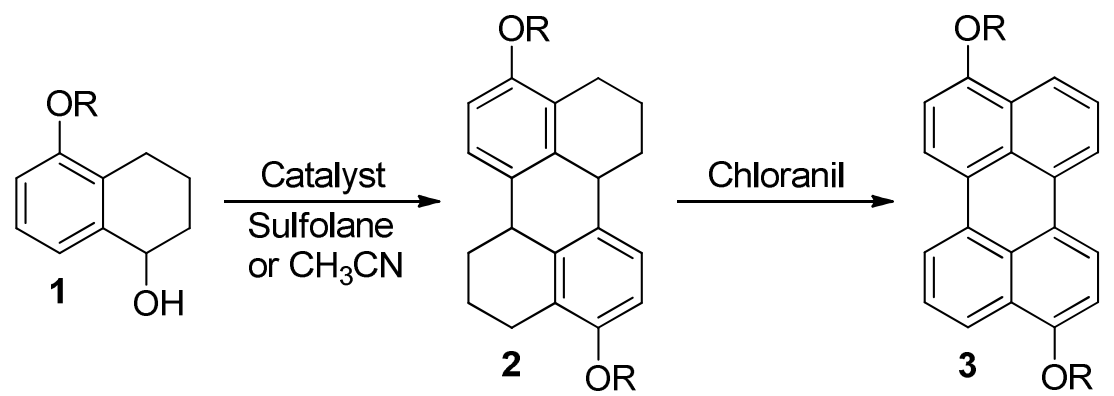

a: $\mathrm{R}=\mathrm{H} ; \mathbf{b}: \mathrm{R}=$ methyl; $\mathbf{c}: \mathrm{R}=n$-octyl; $\mathbf{d}: \mathrm{R}=$ allyl $\quad$ 3,9-diallyloxyperylene Catalyst: $\mathrm{TsOH}, \mathrm{BF}_{3} \cdot \mathrm{Et}_{2} \mathrm{O}, \mathrm{Sc}(\mathrm{OTf})_{3}$, or $\mathrm{Hf}(\mathrm{OTf})_{4}$

Scheme 1. Tandem Friedel-Crafts annulation.

Prior studies demonstrated that 1,2,3,4-tetrahydronaphth-1,5-diol $(\mathbf{1 a}: \mathrm{R}=\mathrm{H})$ and corresponding ethers $\left(\mathbf{1 b}: \mathrm{R}=\mathrm{CH}_{3}\right.$ and $\left.\mathbf{1 c}: \mathrm{R}=\left(\mathrm{CH}_{2}\right)_{7} \mathrm{CH}_{3}\right)$ are suitable substrates for TFCA, each generating the corresponding octahydroperylene (2) in modest to good yields. ${ }^{5}$ Allyl ether 1d $\left(\mathrm{R}=\right.$ allyl), ${ }^{7}$ also produced 2d upon TFCA. Aryl esters of $\mathbf{1}$ (for example, $\mathrm{R}=\mathrm{COCH}_{3}$ or $\left.\mathrm{CO}\left(\mathrm{CH}_{2}\right)_{6} \mathrm{CH}_{3}\right)$, however, were resistant to TFCA, presumably due to the reduction of both aryl nucleophilicity and carbocation intermediate stability, limiting the scope of this transformation. We envisaged a modified route to additional dyes in which key intermediate $\mathbf{2 d}(\mathrm{R}=$ allyl $)$ is transformed to 5 via sequential Claisen rearrangement and oxidation steps (Scheme 2). Novel product 5a and its ether $(\mathrm{R}=$ alkyl $)$ derivatives are predicted to be easily elaborated to perylenes that are electronically activated toward photoemission. ${ }^{8}$ Conversion from known $\mathbf{2 d}$ to $\mathbf{5 b}$ was planned via Claisen rearrangement followed by oxidation (Route A) or the reverse sequence (Route B). The former requires the preparation of acylated octahydroperylene intermediate $4 \mathbf{b}$ en route to $\mathbf{5 b}$ to avoid phenolic oxidation to quinones. ${ }^{5,8}$ In the present work, we examined feasibility of both synthetic avenues to 5 . 


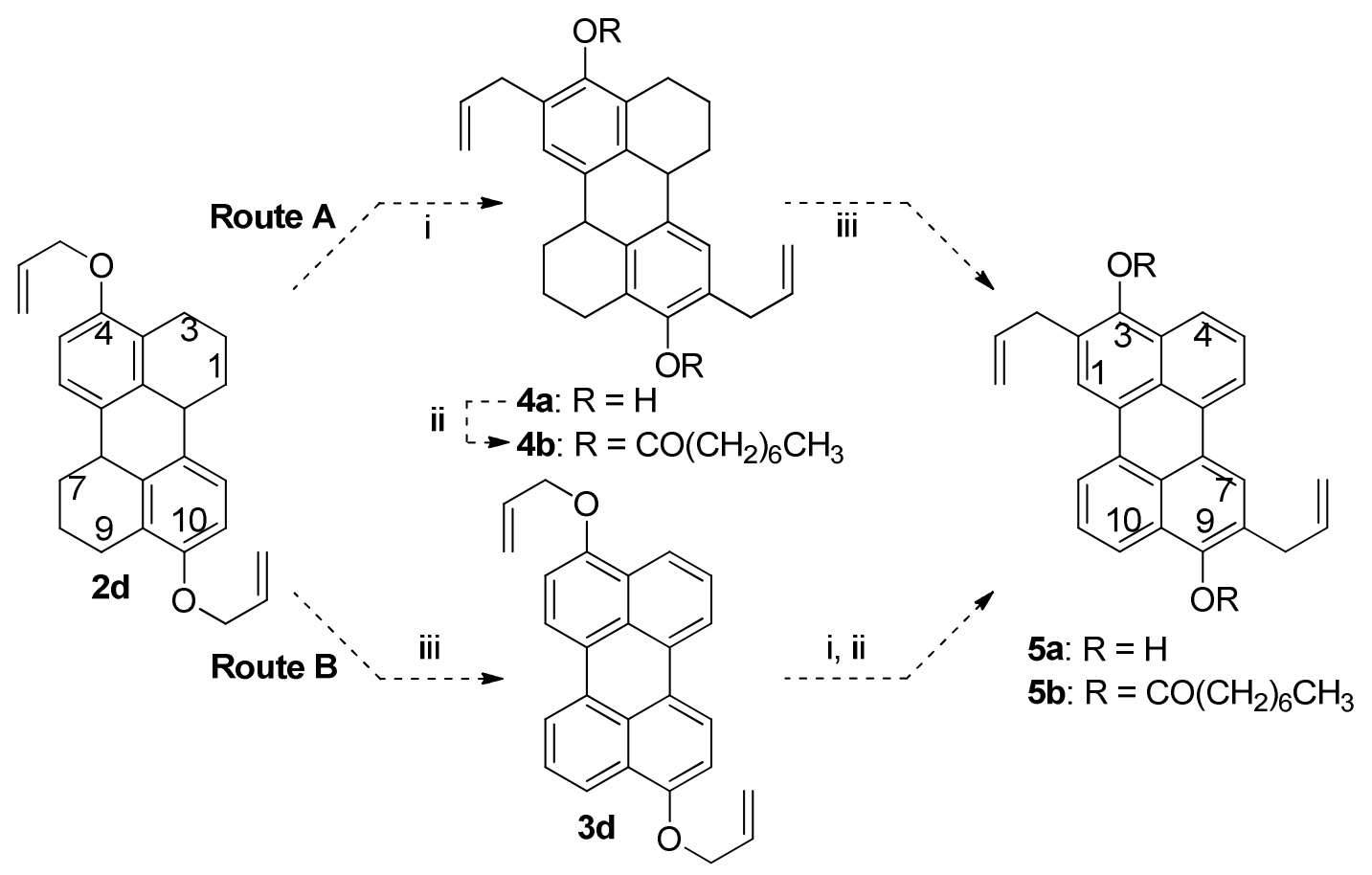

Conditions: i) $190^{\circ} \mathrm{C} /$ neat (Route A) or $180^{\circ} \mathrm{C} / \mathrm{Me}_{2} \mathrm{PEG}$ (Route B);

ii) $\mathrm{CH}_{3}\left(\mathrm{CH}_{2}\right)_{6} \mathrm{COCl} /$ pyridine/0 ${ }^{\circ} \mathrm{C}$ to $\mathrm{RT}$; iii) chloranil/toluene/RT

Scheme 2. Proposed routes to 2,8-diallyl-3,9-diacyloxyperylene.

\section{Results and Discussion}

Phenolic allylation of 1,2,3,4-tetrahydronaphth-1,5-diol occurred smoothly in refluxing acetone (allyl bromide, $\mathrm{K}_{2} \mathrm{CO}_{3}$, acetone) to provide $1 \mathbf{d}(\mathrm{R}=$ allyl; 90\%). The physical and spectral properties of 1d, which had not been previously disclosed, are consistent with expectations. Tandem Friedel-Crafts annulation of $\mathbf{1 d}$ (acetonitrile, $\mathrm{BF}_{3} \cdot \mathrm{OEt}_{2}, 0{ }^{\circ} \mathrm{C}, 2 \mathrm{~h}$ ) gave the corresponding octahydroperylene $\mathbf{2 d}$ in improved yield (60\%) compared to the established protocol. ${ }^{5}$ The product from this transformation, which precipitated during the reaction, was obtained in high purity, enabling its direct use in subsequent synthetic steps.

Efforts to implement Route A commenced upon examination of the thermal Claisen rearrangement of $\mathbf{2 d}$ to $\mathbf{4 a}$ under conditions established in this laboratory for the rearrangement of allyloxybenzene. Thus, solvent-free heating of solid $\mathbf{2 d}\left(190{ }^{\circ} \mathrm{C}, 10 \mathrm{~h}\right)$ gave a black solid that exhibited loss of ${ }^{1} \mathrm{H}$ NMR signal at $4.8 \mathrm{ppm}$ (allyloxy methylene of $2 \mathbf{d}$ ) and concurrent emergence of a complex multiplet between 3.0-3.5 ppm, both suggesting Claisen rearrangement. However, multiple doublets in the 7.8-8.0 ppm region of ${ }^{1} \mathrm{H}$ NMR were consistent with oxidation of the polycyclic core to the corresponding anthracenyl or perylenyl products. The spectrum was further complicated by the presence of multiple vinyl signals indicating multiple 
products. Because each of these products consists of similar $\mathrm{R}_{\mathrm{f}}$ value in TLC, no further studies were conducted on this pathway to avoid difficult purification steps.

To investigate the feasibility of Route B, chloranil oxidation of $\mathbf{2 d}$ (4 equiv, toluene, room temperature) was examined. This transformation and others producing analogues with fully aromatized perylene cores were protected from ambient light to avoid photodegradation. An aliquot of the incomplete reaction was strongly fluorescent and exhibited new signals at 7.8 to $8.0 \mathrm{ppm}$ in ${ }^{1} \mathrm{H}$ NMR, suggesting the partial oxidation of $\mathbf{2 d}$ to the anthracenyl derivative. Continued exposure of the sample to chloranil (60 h total) induced clean conversion to 3d (Scheme 2), as indicated by the expected aromatic resonances given in ${ }^{1} \mathrm{H}$ NMR spectrum. The product, which precipitated in the reaction milieu, was filtered, washed with acetonitrile/MeOH (1:1), and dried under vacuum to give a greenish yellow solid in good yield (72\%). Product 3d was poorly soluble in available NMR solvents $\left(\mathrm{CDCl}_{3}\right.$, acetone- $d_{6}$, acetonitrile- $d_{3}$, DMSO- $d_{6}$, THF- $d_{8}$, benzene- $d_{6}$ ), precluding the collection of ${ }^{13} \mathrm{C}$ NMR data. ${ }^{5}$

Thermal Claisen rearrangement of $\mathbf{3 d}$ under solvent-free conditions $\left(150{ }^{\circ} \mathrm{C} ; 4 \mathrm{~h}\right)$ gave a darkened product that was shown to be mainly unreacted substrate by ${ }^{1} \mathrm{H}$ NMR. At higher temperature $\left(180{ }^{\circ} \mathrm{C}\right)$ the product was extensively decomposed. Since the Claisen rearrangement of structurally similar 1-allyloxynaphthalene proceeds at $150{ }^{\circ} \mathrm{C}(2 \mathrm{~h}, 98 \%$ conversion), the failure of the rearrangement of $\mathbf{3 d}$ at this temperature likely results from inhibition caused by the solid physical state of the perylene core. ${ }^{9}$ Thermal rearrangement of $\mathbf{3 d}$ in 1,2-dichlorobenzene at $150{ }^{\circ} \mathrm{C}$ gave degraded product as determined by ${ }^{1} \mathrm{H}$ NMR. Heating $3 \mathbf{d}$ in a minimum amount of polyethylene glycol dimethyl ether $\left(2 \mathrm{~h}, 180{ }^{\circ} \mathrm{C}\right)$ gave targeted product 5 a contaminated with unidentified byproducts. Several attempts made to produce clean $\mathbf{5 a}$ were unsuccessful, possibly due to facile product oxidation. To facilitate isolation and purification of a derivative of $\mathbf{5}$, the Claisen rearrangement was followed by acylation in situ $\left(\mathrm{ClCO}\left(\mathrm{CH}_{2}\right)_{6} \mathrm{CH}_{3}\right.$, pyridine, $0{ }^{\circ} \mathrm{C}$ to $\left.\mathrm{rt}\right)$, which gave $\mathbf{5 b}$ in good yield after chromatography $(56 \%$ yield). Product $\mathbf{5 b}$ exhibited the expected spectroscopic signals including UV/vis profile with the typical perylene absorbance pattern. ${ }^{8}$

These findings establish a pathway for novel, electron-rich diallyldihydroxyperylene and its diester. ${ }^{10}$ The products support potential sites for ligation or chemical modification en route to novel photoactive materials, which are under investigation in our laboratory and those of collaborators.

\section{Conclusions}

Tetrasubstituted, electron-rich perylene analogues $\mathbf{5 a}$ and $\mathbf{5 b}$ were prepared in 4 and 5 steps, respectively from commercially available 1,2,3,4-tetrahydronaphth-1,5-diol in good overall efficiency. The present sequence generates electron rich perylene cores that support olefinic and alkoxy groups, which may be employed for subsequent tethering to materials for photonic applications. 


\section{Experimental Section}

General. Melting points were measured on a Mel-Temp apparatus. Proton NMR and ${ }^{13} \mathrm{C}$ NMR spectra were recorded at $500 \mathrm{MHz}$ and $125 \mathrm{MHz}$ (Varian INOVA), respectively, in $\mathrm{CDCl}_{3}$ at 25 ${ }^{\circ} \mathrm{C}$ unless otherwise noted. Chemical shift values are reported in ppm with TMS as reference at $0.00 \mathrm{ppm}$ for proton and $\mathrm{CDCl}_{3}$ carbon residue at $77.0 \mathrm{ppm}$ for ${ }^{13} \mathrm{C}$ spectra. Spin-spin coupling constants $(J)$ are given in Hz. Mass (Finnigan LCQ DUO) and FT-IR (Bruker Vector 22) spectra were recorded using APCI and ATR technology, respectively, unless otherwise noted. Kieselgel $60 \mathrm{~F}_{254}$ silica gel TLC plates were used with ethyl acetate and hexanes as solvents for monitoring reaction progress. All necessary chemicals were purchased in $98 \%$ or better purities and used without purification.

5-Allyloxy-1,2,3,4-tetrahydronaphthalen-1-ol (1d). A mixture of 1,2,3,4-tetrahydronaphth-1,5diol $1 \mathrm{a}(2.00 \mathrm{~g}, 12 \mathrm{mmol}), \mathrm{K}_{2} \mathrm{CO}_{3}(1.60 \mathrm{~g}, 48 \mathrm{mmol})$, and allyl bromide (1.00 mL, $\left.12 \mathrm{mmol}\right)$ in acetone was refluxed $24 \mathrm{~h}$ under $\mathrm{N}_{2}$. The reaction mixture was extractively processed with ethyl acetate/water, and the organic layer was dried over $\mathrm{Na}_{2} \mathrm{SO}_{4}$, evaporated in vacuo, and chromatographed (silica gel, ethyl acetate/hexanes 1:3) to provide $\mathbf{1 d}$ as a white amorphous solid in good yield, $1.62 \mathrm{~g}(90 \%)$, mp 56-57 ${ }^{\circ} \mathrm{C} ;{ }^{1} \mathrm{H}$ NMR $\left(\mathrm{CDCl}_{3}, 500 \mathrm{MHz}\right): \delta_{\mathrm{H}} 1.75-1.84(\mathrm{~m}, 2 \mathrm{H})$, 1.87-1.99 (m, 2H), 2.58-2.65 (m, 1H), 2.80-2.86 (m, 1H), $4.56(\mathrm{~d}, J 2.5 \mathrm{~Hz}, 2 \mathrm{H}), 4.80(\mathrm{~s}, 1 \mathrm{H})$, $5.30(\mathrm{dd}, J 2.0 \mathrm{~Hz}, 7.5 \mathrm{~Hz}, 1 \mathrm{H}), 5.45(\mathrm{dd}, J 3 \mathrm{~Hz}, 10 \mathrm{~Hz}, 1 \mathrm{H}), 6.04-6.12(\mathrm{~m}, 1 \mathrm{H}), 6.76$ (d, J 10

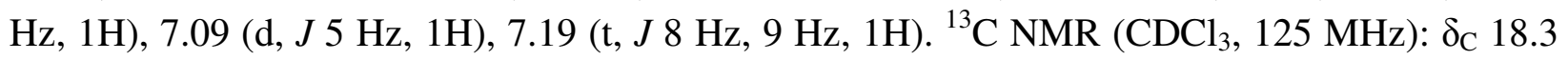
(dd), 23.3 (d), 31.9 (d), 68.3 (d), 68.9 (t), 110.1 (d), 117.2 (d), 120.9 (d), 126.6 (dd), 133.7 (m), 140.2 (s), 156.2 (s). IR ( $\left.v_{\max }, \mathrm{cm}^{-1}\right)$ : 665, 773, 885, 966, 1232, 1633, 1675, 2784, 2856, 2976, 3018, 3352. $\mathrm{MS}(\mathrm{m} / \mathrm{z}): 371.5\left(\mathrm{M}_{2}^{+}-2 \mathrm{H}_{2} \mathrm{O}-\mathrm{H}, 69\right), 227.5\left(\mathrm{M}+\mathrm{Na}^{+}, 30\right), 204.4\left(\mathrm{M}^{+}, 30\right), 187.4\left(\mathrm{M}^{+}-\right.$ $\mathrm{OH}, 100)$. HRMS calcd for $\mathrm{C}_{13} \mathrm{H}_{16} \mathrm{O}_{2}\left(\mathrm{MH}^{+}\right)$: 204.1150. Found: 204.1102.

4,10-Diallyloxy-1,2,3,6b,7,8,9,12b-octahydroperylene (2d). Allyl aryl ether $1 \mathrm{~d}$ (173 mg, 0.85 $\mathrm{mmol})$ in acetonitrile $(5 \mathrm{~mL})$ was cooled to ice bath temperature, treated with $\mathrm{BF}_{3} \bullet \mathrm{Et}_{2} \mathrm{O}(0.5 \mathrm{~mL})$ by fast dropwise addition, and the mixture was stirred for $2 \mathrm{~h}$ at $0{ }^{\circ} \mathrm{C}{ }^{7}$ An off-white solid was collected by filtration, triturated with acetone, and dried under vacuum. The solid (2d) was of sufficient purity for direct use in the succeeding oxidation, $80 \mathrm{mg}(60 \%), \mathrm{mp} 185-188{ }^{\circ} \mathrm{C} ;{ }^{1} \mathrm{H}$ NMR $\left(\mathrm{CDCl}_{3}, 500 \mathrm{MHz}\right): \delta_{\mathrm{H}} 1.51(\mathrm{tt}, J 12.2 \mathrm{~Hz}, 8.3 \mathrm{~Hz}, 2 \mathrm{H}), 1.69-1.79(\mathrm{~m}, 2 \mathrm{H}), 2.00-2.10(\mathrm{~m}$, 2H), $2.53(\mathrm{dt}, J 16.1 \mathrm{~Hz}, 7.8 \mathrm{~Hz}, 2 \mathrm{H}), 2.51-2.58$ (m, 2H), 3.15 (ddd, J 16.1 Hz, 6.8 Hz, $5.4 \mathrm{~Hz}$, 2H), 3.73 (dd, $J 11.7 \mathrm{~Hz}, 4.4 \mathrm{~Hz}, 2 \mathrm{H}), 4.51-4.59$ (m, two ABX patterns, 4H), 5.27 (dq, $J 10.8$ $\mathrm{Hz}, 1.5 \mathrm{~Hz}, 2 \mathrm{H}), 5.44(\mathrm{dq}, J 17.1 \mathrm{~Hz}, 1.5 \mathrm{~Hz}, 2 \mathrm{H}), 6.95$ (ddt, $J 17.1 \mathrm{~Hz}, 10.8 \mathrm{~Hz}, 5.4 \mathrm{~Hz}, 2 \mathrm{H})$, $6.82(\mathrm{~d}, J 7.8 \mathrm{~Hz}, 2 \mathrm{H}), 7.23(\mathrm{~d}, J 8.3 \mathrm{~Hz}, 2 \mathrm{H}) .{ }^{13} \mathrm{C} \mathrm{NMR}\left(\mathrm{CDCl}_{3}, 125 \mathrm{MHz}\right): \delta_{\mathrm{C}} 20.9(\mathrm{t}), 21.2(\mathrm{t})$, 29.9 (t), 36.1 (d), 69.3 (t), 110.1 (d), 116.9 (dd), 124.5 (d), 126.7 (s), 128.2 (s), 133.9 (d), 136.9 (s), $153.5(\mathrm{~s})$. IR $\left(v_{\max }, \mathrm{cm}^{-1}\right): 675,775,874,925,1294,1414,1651,1666,2792,2877,2991$, 3005, 3020. MS (m/z): $373.2\left(\mathrm{MH}^{+}, 60\right), 372.3\left(\mathrm{M}^{+}, 45\right), 332.3\left(\mathrm{MH}^{+}-\mathrm{CH}_{2} \mathrm{CH}: \mathrm{CH}_{2}, 42\right), 331.4$ $\left(\mathrm{M}^{+}-\mathrm{CH}_{2} \mathrm{CH}: \mathrm{CH}_{2}, 100\right)$, $289.6\left(\mathrm{MH}^{+}-2 \mathrm{CH}_{3} \mathrm{CH}: \mathrm{CH}_{2}, 15\right)$. HRMS Calcd for $\mathrm{C}_{26} \mathrm{H}_{28} \mathrm{O}_{2}\left(\mathrm{M}^{+}\right)$: 372.2089. Found: 372.2085. 
3,9-Diallyloxyperylene (3d). A mixture of $2 \mathbf{d}(0.44 \mathrm{~g}, 2.5 \mathrm{mmol})$ and chloranil $(2.45 \mathrm{~g}, 10$ mmol) in toluene/acetonitrile (11:1) was heated at $45{ }^{\circ} \mathrm{C}$ for $20 \mathrm{~h}$ under $\mathrm{N}_{2}$. The resultant solid was filtered and washed sequentially with acetonitrile and methanol to generate $\mathbf{3 d}$ as a greenish yellow solid in good yield, $0.32 \mathrm{~g}(72 \%), \mathrm{mp} 226-228{ }^{\circ} \mathrm{C} ;{ }^{1} \mathrm{H} \mathrm{NMR}\left(\mathrm{CDCl}_{3}, 500 \mathrm{MHz}\right): \delta_{\mathrm{H}} 4.78$ $(\mathrm{d}, J 6 \mathrm{~Hz}, 4 \mathrm{H}), 5.35(\mathrm{~d}, J 5 \mathrm{~Hz}, 2 \mathrm{H}), 5.43(\mathrm{~d}, J 10 \mathrm{~Hz}, 2 \mathrm{H}), 6.11-6.20(\mathrm{~m}, 2 \mathrm{H}), 6.81(\mathrm{~d}, J 4 \mathrm{~Hz}$, 2H), $7.41(\mathrm{t}, J 2,3 \mathrm{~Hz}, 2 \mathrm{H}), 8.10(\mathrm{~m}, 4 \mathrm{H}) . \mathrm{IR}\left(\mathrm{v}_{\max }, \mathrm{cm}^{-1}\right): 785,802,915,1080,1249,1447$, 1581, 2862, 2897, 3062. MS (m/z): $365.2\left(\mathrm{MH}^{+}, 46\right), 323.3\left(\mathrm{M}^{+}-\mathrm{CH}_{2} \mathrm{CH}: \mathrm{CH}_{2}, 100\right), 282.5\left(\mathrm{M}^{+}-\right.$ $\left.2 \mathrm{CH}_{2} \mathrm{CH}: \mathrm{CH}_{2}, 29\right)$. HRMS Calcd for $\mathrm{C}_{26} \mathrm{H}_{20} \mathrm{O}_{2}\left(\mathrm{M}^{+}\right)$: 364.1463. Found: 364.1478.

2,8-Diallyl-3,9-dioctanoyloxyperylene (5b). Diallyloxyperylene 3d (0.100 g, $0.30 \mathrm{mmol})$ was dissolved in polyethylene-glycol dimethyl ether $(1.0 \mathrm{~mL})$ and heated at $180{ }^{\circ} \mathrm{C}$ for $2 \mathrm{~h}$ under $\mathrm{N}_{2}$ while stirring. The mixture was removed from heat, cooled to ice bath temperature, and pyridine $(2 \mathrm{~mL})$ and octanoyl chloride $(0.21 \mathrm{~mL}, 1.2 \mathrm{mmol})$ were added with agitation. After overnight stirring the sample was taken up in toluene $(2 \times 5 \mathrm{~mL})$ and the combined organic layers were washed sequentially with brine and $\mathrm{NaHCO}_{3}$ solution to obtain a greenish yellow solution. The solution was then dried over $\mathrm{Na}_{2} \mathrm{SO}_{4}$, evaporated in vacuo, and chromatographed (silica gel; solvent gradient: 3-97\% ethyl acetate in toluene) to obtain pure $\mathbf{5 b}$ as an amorphous yellow solid, $100 \mathrm{mg}(62 \%)$, mp $105-110{ }^{\circ} \mathrm{C} ;{ }^{1} \mathrm{H} \mathrm{NMR}\left(\mathrm{CDCl}_{3}, 500 \mathrm{MHz}\right): \delta_{\mathrm{H}} 0.91(\mathrm{t}, J 8 \mathrm{~Hz}, 6 \mathrm{H})$, 1.26-1.42 (m, 12H), 1.42-1.48 (m, 4H), 1.84-1.93 (m, 4H), 2.68-2.81 (m, 4H), 3.42-3.50 (m, $4 \mathrm{H}), 5.24(\mathrm{t}, J 5 \mathrm{~Hz}, 10 \mathrm{~Hz}, 4 \mathrm{H}), 5.98-6.05(\mathrm{~m}, 2 \mathrm{H}), 7.48-7.59(\mathrm{~m}, 2 \mathrm{H}), 7.60(\mathrm{~d}, J 5 \mathrm{~Hz}, 2 \mathrm{H})$, $8.10(\mathrm{~s}, 2 \mathrm{H}), 8.20(\mathrm{~d}, J 5 \mathrm{~Hz}, 2 \mathrm{H}) .{ }^{13} \mathrm{C} \mathrm{NMR}\left(\mathrm{CDCl}_{3}, 125 \mathrm{MHz}\right): \delta_{\mathrm{C}} 14.3(\mathrm{t}), 22.8(\mathrm{q}), 25.3(\mathrm{q})$, 29.2 (q), 29.5 (q), 31.9 (q), 34.4 (t), 35.2 (d), 117.0 (t), 120.4 (d), 121.0 (t), 122.4 (d), 127.4 (s), $128.4(\mathrm{t}), 128.6(\mathrm{~s}), 129.2(\mathrm{~s}), 129.3(\mathrm{~s}), 131.1(\mathrm{~s}), 135.8(\mathrm{q}), 144.4(\mathrm{~s}), 172.3(\mathrm{~s})$. IR $\left(\mathrm{v}_{\max }, \mathrm{cm}^{-1}\right)$ : 762, 906, 1138, 1596, 1615, 1639, 1748, 2850, 2917, 3051. MS (m/z): $617.0\left(\mathrm{MH}^{+}, 5\right), 491.1$ $\left(\mathrm{MH}^{+}-\mathrm{COC}_{7} \mathrm{H}_{14}, 47\right), 450.2\left(\mathrm{MH}^{+}-\left(\mathrm{COC}_{7} \mathrm{H}_{14}+\mathrm{CH}_{2} \mathrm{CH}: \mathrm{CH}_{2}\right), 21\right), 365.4\left(\mathrm{MH}^{+}-2 \mathrm{COC}_{7} \mathrm{H}_{14}, 44\right)$, $364.5\left(\mathrm{M}^{+}-2 \mathrm{COC}_{7} \mathrm{H}_{14}, 100\right), 324.6\left(\mathrm{MH}^{+}-\left(2 \mathrm{COC}_{7} \mathrm{H}_{14}+\mathrm{CH}_{2} \mathrm{CH}: \mathrm{CH}_{2}\right)\right.$, 35). HRMS Calcd for $\mathrm{C}_{42} \mathrm{H}_{49} \mathrm{O}_{4}\left(\mathrm{MH}^{+}\right)$: 617.3625. Found: 617.3599.

\section{Acknowledgements}

We are grateful for Collaborative Research Seed Grant Program (CRSGP) funds provided by the Office of the Vice President for Research at the University of Texas at San Antonio. MAP was funded to conduct studies by the CRSGP.

\section{References}

1. For reviews see: (a) Huang, C.; Barlow, S.; Marder, S. R. J. Org. Chem. 2011, 76, 2386. (b) Harvey, R. in Polycyclic Aromatic Hydrocarbons; Wiley-VCH: New York, NY, USA, 1997; pp 151-155. (c) Langhals, H. Heterocycles 1995, 40, 477. For spectral fluorescence data see: 
(d) Berlman, B. I. Handbook of Fluorescence Spectra of Aromatic Molecules; Academic Press: New York, NY, 1971.

2. Wang; S.-L.; Ho, T.-I. Photochem. Photobiol. A: Chem. 2000, 135, 119.

3. (a) Shin, W. S.; Jeong, H.-H.; Kim, M.-K.; Jin, S.-J.; Kim, M.-R.; Lee, J.-K.; Lee, J. W.; Gal, Y.-S. J. Mater. Chem. 2006, 16, 384. (b) Shirman, E.; Ustinov, A.; Ben-Shitrit, N.; Weissman, H.; Iron, M. A.; Cohen, R.; Rybtchinski, B. J. Phys. Chem. B 2008, 112, 8855.

4. Banning, J. H.; Jones, M. B. Polycyclic Arom. Compds. 1991, 2, 107.

5. Penick, M. A.; Mahindaratne, M. P. D.; Gutierrez, R. D.; Smith, T. D.; Tiekink, E. R. T.; Negrete, G. R. J. Org. Chem. 2008, 73, 6378.

6. For example, see: (a) Erten-Ela, S.; Yilmaz, M. D.; Içli, B.; Dede, Y.; Içli, S.; Akkaya, E. U. Org. Lett. 2008, 10, 3299. (b) Wang, Q.; Campbell, W. M.; Bonfantani, E. E.; Jolley, K. W.; Officer, D. L.; Walsh, P. J.; Gordon, K.; Humphry-Baker, R.; Nazeeruddin, M. K.; Grätzel, M. J. Phys. Chem. B 2005, 109, 15397. (c) Hara, K.; Sato, T.; Katoh, R.; Furube, A.; Yoshihara, T.; Murai, M.; Kurashige, M.; Ito, S.; Shinpo, A.; Suga, S.; Arakawa, H. Adv. Funct. Mater. 2005, 15, 246.

7. Additional characterization details of compound $\mathbf{2 d}$ can be found in the following communication: Smith, T. D.; Mahindaratne, M. P. D.; Penick, M. A.; Negrete, G. R.; Daniels, L. M.; Tiekink, E. R. T. Acta Cryst. 2010, E66, o96.

8. Fuini, J. F.; Surampudia, A. B.; Penick, M. A.; Mahindaratne, M. P. D.; Negrete, G. R.; Brancaleon, L. Dyes and Pigments 2011, 88, 204.

9. (a) Moseley, J. D.; Woodman, E. K. Org. Process Res. Dev. 2008, 12, 967. (b) Yamamoto, T.; Wada, Y.; Enokida, H.; Fujimoto, M.; Nakamura, K.; Yanagida, S. Green Chem. 2003, 5, 690.

10. Hansch, C.; Leo, A.; Taft, R. W. Chem. Rev. 1991, 91, 165. 